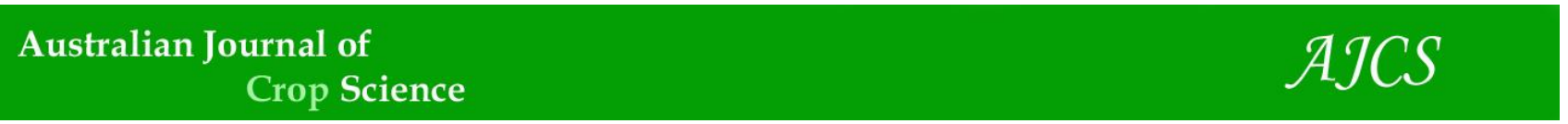

AJCS 15(01):114-118 (2021)

ISSN:1835-2707

doi: 10.21475/ajcs.21.15.01.2920

\title{
Emergence and initial growth of Mimosa bimucronata (DC) O. KTZE. seedlings at different depths and position of sowing
}

\author{
Luan Danilo Ferreira de Andrade Melo ${ }^{1 *}$, João Luciano de Andrade Melo Junior ${ }^{1}$, Lívia Francyne Gomes \\ Chaves ${ }^{1}$, Dougllas Ferreira da Rocha ${ }^{1}$, Maria Inajal Rodrigues da Silva das Neves ${ }^{1}$, Edilma Pereira \\ Gonçalves ${ }^{2}$, Wesley Oliveira de Assis ${ }^{1}$, Reinaldo de Alencar Paes ${ }^{1}$, Aldair de Souza Medeiros ${ }^{1}$, Ivomberg \\ Dourado Magalhães ${ }^{1}$, Natália Marinho Silva Crisostomo ${ }^{1}$
}

\author{
${ }^{1}$ Department of Agroecology and Agronomy, University Federal of Alagoas - UFAL, Brazil \\ ${ }^{2}$ Department of Agronomy, University Federal of Agreste of Pernambuco, UFAPE, Brazil
}

\section{*Corresponding author: Iuan.danilo@yahoo.com.br}

\begin{abstract}
Mimosa bimucronata (DC) O. KTZE. (maricá), belong to the family Fabaceae is a forest species found in Latin America. This species has been used in landscaping, reforestation and restoration of degraded areas and permanent preservation. The present work aimed to verify the effect of the position of the seed and the depth of sowing in the emergence and initial growth of seedlings of $M$. bimucronata. The experiment was carried out in a completely randomized design with four replications including 25 seeds per treatment. Different positions of the seeds were used in the sand substrate: downward facing (HB) thread; facing the side, forming an angle of $90^{\circ}$ to the imaginary axis with the substrate (HL); and upward facing wire (HC), at seeding depths of 1, 2, 3, 4, 5 and 6 $\mathrm{cm}$. The following variables were evaluated: emergence percentage, first count and emergence speed index, seedling length and dry mass. The results showed that $\mathrm{HL}$ at a depth of $1 \mathrm{~cm}$ sowing produces higher vigor seedlings.
\end{abstract}

Keywords: Maricá, Mimosaceae, Hilo, Reforestation, Vigor.

Abbreviations: HB_downward hilum; HC_upwardly hyl; HL_hilo to the side; ISE_Index of Speed Emergency.

Introduction

The Mimosa bimucronata (De Candolle) Otto Kuntze belongs to the following hierarchy: division: Magnoliophyta; (Angiospermae); class: Magnoliopsida (Dicotiledonae); order: Fabales; family: Fabaceae (LeguminosaeMimosoideae); species: Mimosa bimucronata (De Candole) Otto Kuntze. Its common names are: maricá, alagadiço, amorosa, angiquinho, arranha-gato, espinheira, espinheirade-cerca, espinheira-de-maricá, espinheiro (Carvalho, 2004). It is a pioneer tree of the Family Fabaceae, endemic of Latin America. It occurs in the Northeast, Midwest, Southeast and South of Brazil, where phytogeographic domain covers the Caatinga, Cerrado and Atlantic Forest. Plants of this species can be used as animal feed, in beekeeping, in medicinal folk use, and its seeds can be stored for years without loss of viability and vigor (Melo et al., 2018).

In recent years, there has been an increase in studies related to seed technology of native species, due to the need for ecosystem recovery and conservation (Pastorini et al., 2016). However, considering the great diversity of species, the available information is still scarce.

Unsuccessful seedling emergence and initial establishment of seedlings in the field for reforestation purposes, may be due to factors such as seed contact with the soil, displacement of the sowing point, very deep sowing, excess or scarcity of moisture and loss of seeds and seedlings by the action of insects and birds (Carvalho and Nakagawa, 2012). Thus, the speed and uniformity of the emergency process are desirable characteristics in the formation of seedlings because the longer the seedling period remains in the early stages of development the longer it will be exposed to adverse environmental conditions (Melo Junior et al., 2018). The depth and sowing position must be adequate to guarantee seed germination, seedling emergence and development (Montanha et al., 2018). The sowing depth is specific to each species, and when appropriate, it provides uniform germination and emergence of seedlings, as excessive sowing depths can prevent the still fragile seedling from emerging to the soil surface. However, they predispose the seeds to any environmental variation, such as excess or water or thermal deficit, which can give rise to small and weak seedlings, if reduced (Machado et al., 2018). In this sense, very deep sowing makes the seedling emergence and increases the period of susceptibility to pathogens (Marcos Filho, 2015). On the other hand, shallow sowing can facilitate the attack of predators or damage resulting from irrigation or the exposure and destruction of the primary root (Montanha et al., 2018).

Studies regarding the effect of seed depth and position at the time of sowing of different forest species on the initial development of seedlings indicated that these effects may 
manifest positively or negatively. Nascimento et al. (2003) and Silva et al. (2007), verified smaller and larger initial development of seedlings of Oenocarpus mapora and Euterpe oleraceae, respectively, as a function of seed position and depth at sowing time.

Although several studies address this issue, but there is no recommendation in the literature for Mimosa bimucronata. The aim of this study was to verify the effect of seed position and depth of sowing on emergence and initial growth of $M$. bimucronata seedlings.

\section{Results and discussion}

\section{Seed emergence}

The water content of $M$. bimucronata seeds at the time of the experiment was around 9\%, which was in accordance with the recommendations of Carvalho and Nakagawa (2012) for the installation of germination and vigor tests. The percentage of seedling emergence was decreased with increasing sowing depth (Figure 1), regardless of the position that they were sown. For sowing in the hil to the side position $(\mathrm{HL}), 100 \%$ emerged seedlings were found at a depth of $1 \mathrm{~cm}$, for those whose hilo was directed downward and hilo upwards, there was a marked linear decrease in emergence percentage with increasing sowing depth. The best seed performance was observed, when sowing was performed in side-directed hil $(\mathrm{HL})$ position at all depths.

According to the results, it was noted that at a depth of 1 cmM. bimucronata seeds presented high emergence percentages, regardless of position. This is an important characteristic for the perpetuation of the species during dissemination of seeds, when they fall down.

This reduction in the percentage of emergence must be related to the increase in the physical barrier provided by the greater depths. According to Silva et al. (2007), chemical composition is also an obstacle that the seeds will have to overcome, while they consume greater amount of reserves. Perez et al. (1999) reported that there was a reduction in the percentage and speed of emergence in Peltophorum dubium (Spreng.) Taub. Seedlings, when the sowing depth was increased.

The position and depth of sowing influenced the emergence of seedlings of some species, such as Erythrina velutina Willd. They expressed the maximum emergence (99\%) at a depth of $1.82 \mathrm{~cm}$, when they were sown at the hilo down position. For those those seeds that hilo position was directed upwards, the highest emergence percentage (63\%) was at $1.47 \mathrm{~cm}$ depth, while at $2.04 \mathrm{~cm}$ depth, the highest emergence percentage (89\%) was found for seeds with the hilum to the side (Cardoso et al., 2008).

Similarly, for Cedrela fissilis L., the $2.2 \mathrm{~cm}$ depth provided the seedlings with a better response to the emergence percentage $(67 \%)$ when seeds were sown in hilo facing downwards, while in seeds with hilo for the seedling. In addition, $32 \%$ of seedlings emerged at a depth of $2.18 \mathrm{~cm}$ (Santos et al., 2009).

\section{First count and emergence speed index}

Regarding the first emergence count (Figure 2A) and seedling emergence rate index (Figure 2B) of $M$. bimucronata, a significant decrease in values was observed as the depth increased in all positions ( $H B, H C$ and $H L$ ). Regarding the positions, the best emergence uniformity (first count and emergence speed) was achieved when sowing was performed with a side-directed hilum ( $H L)$ at a depth of $1 \mathrm{~cm}$.

The results found in this study corroborate with those of Martins et al. (1999) when they reported that sowing in the correct position provides rapid and uniform germination. Santos et al. (2009) emphasized that, at greater depths, there is greater concentration of $\mathrm{CO}_{2}$; thus, causing phytotoxic effect, consequently affecting the percentage and speed of emergence.

Similar results were obtained on Erythrina velutina Willd. (Cardoso et al., 2008) and Zizyphus joazeiro Mart., whose values at first count and emergence velocity decreased with increasing sowing depth (Alves et al., 2008). For Cedrela fissilis L., the maximum seedling emergence speed was occurred when sowing was up to $2.17 \mathrm{~cm}$ deep with seeds laid to germinate in the hil down position (Santos et al., 2009). In Amburana cearensis (Allemão), Guedes et al. (2010) observed that, there iss a higher seedling emergence velocity at a depth of $3.5 \mathrm{~cm}$, when sowing was done in hilum facing downwards.

\section{Length of seedlings}

The seedling length of $M$. bimucronata sown in side-facing hilum ( $\mathrm{HL}$ ) position showed a linear decrease as the sowing was deeper, while, with the downward ( $\mathrm{HB}$ ) and upward (HC) hilum, there was no adjustment of the data to regression models, whereas average length was 5.8 and 6.3 $\mathrm{cm}$, respectively (Figure 3 ). When comparing the influence of the positions, it is verified that the shortest seedling lengths were obtained from seeds with the downward (HB) and upward ( $\mathrm{HC}$ ) hil at depths of 5 and $6 \mathrm{~cm}$.

Seedlings from seeds submitted to the highest depths underwent greater physiological wear in the emergence phase, impairing normal development.

Alves et al. (2008) reported a reduction in the seedling length of Zizyphus joazeiro Mart. due to the increase in sowing depth, while the seeds of Erythrina velutina Willd. (Cardoso et al., 2008) and Cedrela fissilis L. (Santos et al., 2009) exhibited the greatest length at the depth of $2.36 \mathrm{~cm}$, put to germinate with the hilum facing the side. Larger seedling length of Amburana cearensis (Allemão) A.C. Smith was obtained from seeds distributed in the side hilum at a depth of $3.4 \mathrm{~cm}$ (Guedes et al., 2010). In contrast, the different sowing positions (upward, sideward and downward apex seed) did not influence the primary root length of Moringa oleifera Lam. seedlings (Sousa et al., 2007).

\section{Dry mass}

The dry mass of $M$. bimucronata seedlings from seedlings germinated with downward facing $(\mathrm{HL})$ and sideward hil $(\mathrm{HL})$ did not fit regression models (Figure 4). However, we observed that, there is a linear decrease at deeper sowing in upward hilum $(\mathrm{HC})$ position. Similar results were obtained by Laime et al. (2010), when they verified that dry mass of Inga ingoides (Rich.) Willd. was increased in seeds sown in hilo down position, while the data does not fit regression models. 


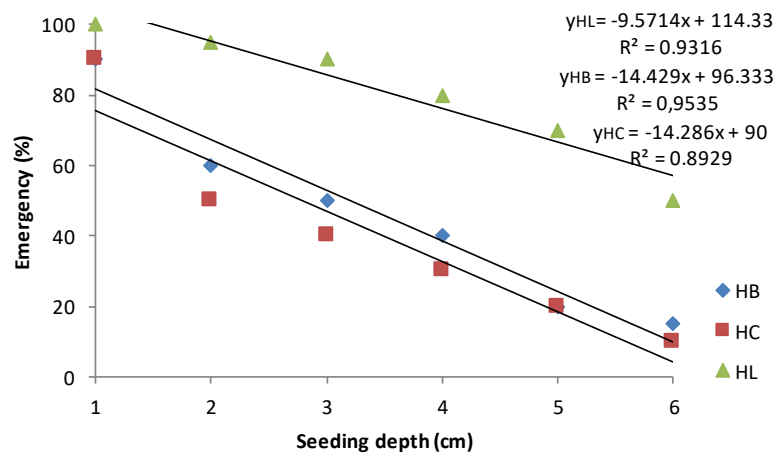

Fig 1. Emergence (\%) of Mimosa bimucronata seedlings as a function of different sowing positions and depths. HB - downward hilum; HC - upwardly hyl; HL - hilo to the side.

2A
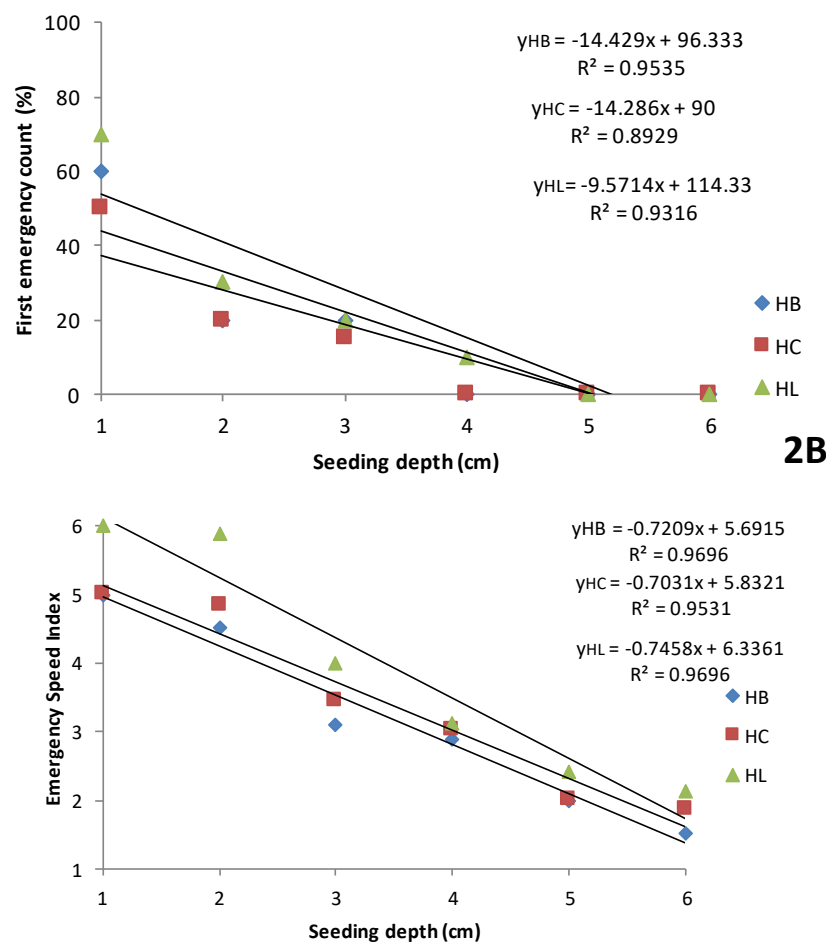

Fig 2. First Count (\%) (2A) and Emergence Speed Index (2B) of Mimosa bimucronata seedlings as a function of different sowing positions and depths. $\mathrm{HB}$ - downward hilum; HC - upwardly hyl; HL - hilo to the side.

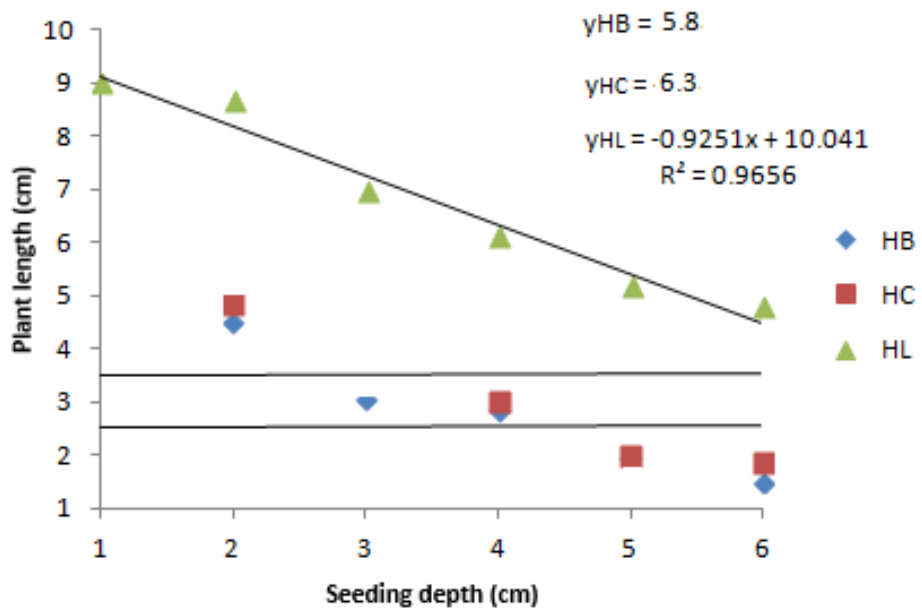

Fig 3. Length of seedlings ( $\mathrm{cm}$ ) of Mimosa bimucronata from seeds submitted to different positions and depth of sowing. HB - downward hilum; HC upwardly hyl; HL - hilo to the side. 


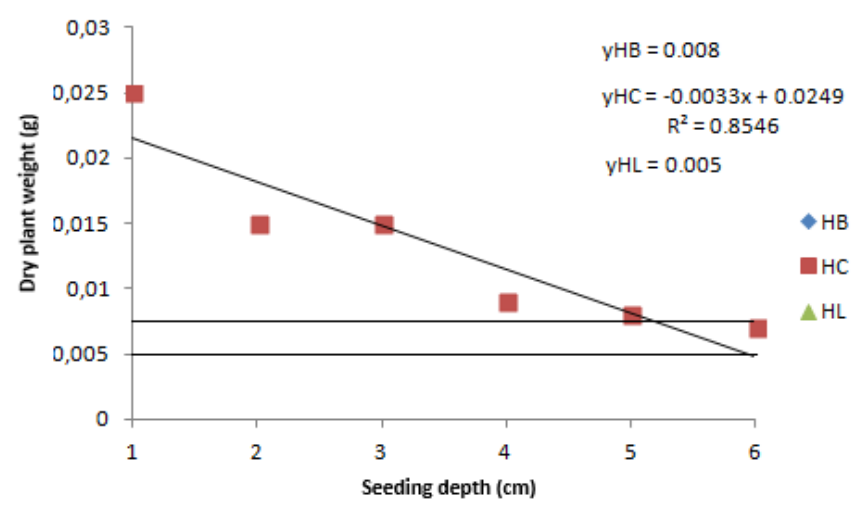

Fig 4. Dry mass of Mimosa bimucronata seedlings (g) from seeds submitted to different positions and depths of sowing. HB - downward hilum; HC upwardly hyl; $\mathrm{HL}$ - hilo to the side.

No significant difference was observed among different depths for the dry mass of the Peltophorum dubim (Spreng) Taubert seedlings, (Perez et al. 1999), and Moringa oleifera Lam seeds (Sousa et al., 2007).

Melo et al. (2018) reported that evaluation of seedling dry mass is of great importance to understand plant development and establishment in the field.

\section{Materials and methods}

\section{Location}

The experiment was conducted at the Laboratory of Fitotecnia, belonging to the Engineering and Agricultural Sciences Campus of the Federal University of Alagoas, Rio Largo, AL, Brazil.

\section{Plant materials}

To obtain the seeds, the ripe fruits were harvested from ten trees belonging to forest fragments located in the municipality of Bom Conselho, PE, situated 09 10'11" S, $36040^{\prime} 47^{\prime \prime} \mathrm{W}$ and 654 meters in altitude.

The fruits were harvested with aerial scissors with extender handle at the end of the maturation period, when color changes from green to dark brown and then kept in the shade (shelter protected from sun and rain) for five days to complete the drying process and facilitate fruit dehiscence.

\section{Overcoming dormancy}

The seeds were mechanically scarified with the aid of pliers, making a cut in the opposite portion of the embryonic axis (Melo et al., 2018).

\section{Substrate}

After overcoming the dormancy, seed were sown in plastic trays $(49 \times 33 \times 7 \mathrm{~cm})$ containing autoclaved washed and sterilized sand at a temperature of $120^{\circ} \mathrm{C}$, for two hours (Brasil, 2009). The composition of the sand was reasonably uniform (most of the particles passed through a sieve with $0.8 \mathrm{~mm}$ holes and was retained over another $0.05 \mathrm{~mm}$ hole). It was free of seeds, fungi, bacteria or toxic substances, which may interfere with the germination of the seeds under test, presented $\mathrm{pH} 6.5$ and sufficient water retention capacity to supply the seeds and seedlings continuously. In addition, it allowed adequate aeration which allowed the emergence and growth of the roots.

\section{Depth, seeding and temperature}

The seeds were sown in different positions, having hilum as reference: seeds with the hilum facing downwards (HB); seeds with the hilum turned to the side, forming an angle of $90^{\circ}$ with the imaginary axis ( $\left.\mathrm{HL}\right)$; and seeds such as hilo facing upwards $(\mathrm{HC})$, at depths of $1,2,3,4,5$ and $6 \mathrm{~cm}$. During the experiment, the trays with the different treatments were packed in a laboratory environment (average temperature $28.9 \circ \mathrm{C}$ ).

\section{Water content}

It was determined by the standard greenhouse method at $105 \pm 3{ }^{\circ} \mathrm{C}$ for 24 hours, as prescribed by the Seed Analysis Rules (Brasil, 2009) with two 2 g seed samples.

\section{Emergency test}

The number of emerged seedlings was evaluated daily in a laboratory for 15 days, with daily irrigation until natural drainage begins.

\section{Index of Speed Emergency (ISE)}

The emergence speed index was determined by daily counting of the number of seedlings emerged during 15 days and the calculation was according to the formula proposed by Maguire (1962).

\section{First Emergency Count}

The first count was performed together with the emergency test, which consisted of the percentage of seedlings emerged at 4 days after sowing.

\section{Length and dry mass seedlings}

After the final emergency test count, the normal seedlings were submitted to measurements from the root base to the seedling apex, with the aid of a ruler graduated in centimeters. They were then placed in Kraft paper bags and 
placed in a dry oven at 65 ㅇ $\mathrm{C}$ until constant weight (48 hours). After this period, they were weighed with precision scale of $0.001 \mathrm{~g}$.

\section{Statistical analysis}

The experimental design was completely randomized, with the treatments distributed in a $3 \times 6$ factorial scheme (positions and depths of sowing), with four replications of 25 seeds for each treatment, whose data were submitted to analysis of variance and polynomial regression equations, when coefficients of determination $\left(R^{2}\right)$ were higher. All analyzes were performed using Sisvar 5.6 statistical software (Ferreira, 2011).

\section{Conclusion}

The position of the Hilo facing the side, at a seeding depth of $1 \mathrm{~cm}$ facilitated the emergence of higher vigor seedlings.

\section{Acknowledgements}

The authors wish to thank the Conselho Nacional de Desenvolvimento Científico e Tecnológico for providing financial support.

\section{References}

Alves EU, Bruno RLA, Alves AU, Cardoso EA, Dornelas CSM, Galindo EA, Braga Júnior JM (2008) Profundidades de semeadura para emergência de plântulas de juazeiro. Cienc Rural. 38: 1158-1161.

Brasil (2009) Ministério da Agricultura, Pecuária e Abastecimento. Regras para análise de sementes. Ministério da Agricultura, Pecuária e Abastecimento. Secretaria de Defesa Agropecuária. Brasília, DF: MAPA/ACS. 395 p.

Cardoso EA, Alves EU, Bruno RLA, Alves AU, Alves AU, Silva KB (2008) Emergência de plântulas de Erythrina velutina em diferentes posições e profundidades de semeadura. Cienc Rural. 38: 2618-2621.

Carvalho PER (2004) Maricá - Mimosa bimucronata. Colombo: Embrapa. 94: 10.

Carvalho NM, Nakagawa J (2012). Sementes: ciência, tecnologia e produção. Jaboticabal: FUNEP, 5: 590.

Ferreira DF (2011) Sisvar: a computer statistical analysis system. Ciênc Agrotec Lavras. 35(6):1039-1042

Guedes RS, Alves EU, Gonçalves EP, Braga-Júnior JM, Viana JS, Colares PNQ (2010) Substratos e temperaturas para testes de germinação e vigor de sementes de Amburana cearensis (Allemão) A.C. Smith. Rev Árvore. 34 (1): 57-64.
Laime EMO, Alves UA, Guedes RS, Silva KB, Oliveira DCS, Santos SS (2010) Emergência e crescimento inicial de plântulas de Inga ingoides (Rich.) Willd. em função de posições e profundidades de semeadura. Semina: Ciênc Agrár. 31(2): 361-372.

Machado TA, Silva CEA, Moura MPA, Buiatti JIBG, Nascimento WV, Santos YAO. Sweet corn (Zea mays var. rugosa) (2018) seedlings emergence at different depths and fertilization systems. Rev Espacios. 39(6): 1-7.

Maguire JD (1962) Seed of germination-aid in selection and evaluation for seedling emergence and vigor. Crop Sci. 2(2):176-177.

Marcos Filho J (2015) Fisiologia de sementes de plantas cultivadas. Piracicaba: FEALQ, 2: 659.

Martins CC, Nakagawa J, Bovi MLA (1999) Efeito da posição da semente no substrato e no crescimento inicial das plântulas de palmito-vermelho (Euterpe espiritusantensis Fernandes Palmae). Rev Bras Sementes. 21(1): 164-173.

Melo LDFA, Melo Junior JLA, Ferreira VM, Araujo Neto JC, Neves MIRS (2018). Biometric characterization and seed germination of giant mimosa (Mimosa bimucronata (DC) O. Kuntze). Aust J Crop Sci. 12: 108-115.

Melo Junior JLA, Melo LDFA, Araújo Neto JC, Ferreira VM (2018) Germination and morphology of seeds and seedlings of Colubrina glandulosa Perkins after overcoming dormancy. Aust J Crop Sci. 12(4):639-647.

Montanha DA, Alves JMA, Silva MR, Matos WS, Silva DCO, Barreto GF (2018) Dormancy-breaking and the influence of sowing depth on seed germination in Desmodium tortuosum. Ver. Agro@mbiente On-line. 12(1): 34-40.

Nascimento CES, Rodal MJN, Cavalcanti AC (2003) Phytosociology of the remaining xerophytic woodland associated to an environmental gradient at the banks of the São Francisco river - Petrolina, Pernambuco, Brazil. Rev. Bras. Botânica. 26(3): 271-287.

Pastorini LH, Romagnolo MB, Barbeiro C, Guerreiro RGO, Costa PM, Souza LA (2016) Germinação e crescimento inicial de Machaerium brasiliense VOGEL (FABACEAE) em casa de vegetação. Rev Floresta. 46(1): 83 - 92.

Perez SCJGA, Fanti SC, Casali CA (1999) Influência do armazenamento, substrato, envelhecimento precoce e profundidade de semeadura na germinação de canafístula. Rev Bragantia. 58(1): 57-68.

Santos SS, Moura MF, Guedes RS, Gonçalves EP, Alves EU, Melo PAFR (2009) Emergência e vigor de plântulas de Cedrela fissilis L. em função de diferentes posições de profundidades de semeadura. Rev Biotemas. 22(4): 45-52.

Silva BMS, Môro FV, Sader R, Kobori NN (2007) Influência da posição e da profundidade de semeadura na emergência de plântulas de açaí (Euterpe oleracea Mart. - Arecaceae). Rev Bras Frut. 29(1): 187-190. 